\title{
Wiara w przestrzeni Ameryki
}

\author{
Recenzja książki: Paulina Napierała, In God We Trust. Religia w sferze \\ publicznej USA, Księgarnia Akademicka, Kraków 2015, 318 stron
}

\author{
Włodzimierz Batóg (iD) http://orcid.org/0000-0003-0527-0299 \\ Instytut Historii \\ Uniwersytet Jana Kochanowskiego w Kielcach \\ e-mail: wlobat@ujk.edu.pl
}

Zainteresowanie tematyką Stanów Zjednoczonych w Polsce wydaje się nie słabnąć i wciąż obejmuje nowe obszary. Tym razem otrzymujemy solidną porcję wiedzy o funkcjonowaniu Kościołów i przejawach religijności w tym kraju od początków jego historii aż do czasów współczesnych.

Monografia Pauliny Napierały ma charakter bardziej prezentacyjny niż analityczny. Na początku autorka wyznacza pięć pól badawczych oraz przedstawia tezę, że ciągły rozwój i przekształcenia amerykańskiej religijności wynikają z rozdziału Kościoła od państwa, prowadzącego do permanentnej transformacji wielkiej energii drzemiącej w wierze Amerykanów. Pozostałe przyczyny to wpływ reformacji i narodzin kapitalizmu, opierającego się na ostrym współzawodnictwie. Kapitalistyczne sposoby na znalezienie nabywców towaru są stosowane również przez przywódców instytucji kościelnych, sfera duchowa podlega bowiem, ze względu na mnogość Kościołów, podlega identycznym prawom co rynek dóbr materialnych. Po kolonizacji kontynentu amerykańskiego poszukiwanie wyznawców przybierało spektakularną formę z powodu niezagospodarowanych przestrzeni geograficznych, gospodarczych czy duchowych, zmuszających do walki o znaczenie, prestiż i obecność w sferze publicznej.

Autorka przyjęła w swych rozważaniach metodologię politologiczną z wykorzystaniem nauk historycznych, socjologicznych, prawnych i religioznawstwa. Niestety, dominuje spojrzenie politologa i prawnika, przez co uwadze autorki umyka wiele istotnych przejawów obecności religii w Stanach Zjednoczonych. Prezentuje religię głównie na tle prawodawstwa i wydarzeń politycznych, mniej uwagi poświęcając jej społecznemu wymiarowi i obecności w życiu codziennym Amerykanów, zwłaszcza 
w drugiej połowie XX wieku. Po analizie literatury, z której korzystała autorka, uderza brak pozycji o charakterze historycznym, szczególnie najnowszych. Szczególnie warto byłoby sięgnąc po pracę Patricka Allitta Religion in America since 1945: A History, wydaną wprawdzie w 2003 roku, ale zawierającą wykaz bardzo dobrej i wieloaspektowo dobranej literatury ze wskazaniem dzieł omawiających wcześniejsze epoki. Brakuje mi także prac z zakresu socjologii religii.

W pracy nie znajdziemy także źródeł pierwotnych (choć autorka o takich wspomina we wstępie) w rozumieniu historycznym, a więc pochodzących ze zbiorów archiwalnych. Napierała nie przeprowadziła odrębnej kwerendy archiwalnej, nie powołuje się na żadne zespoły ani istniejące archiwa, a to, co określa jako źródła, jest zbiorem badań i ankiet na temat trendów we współczesnej religijności, dostępnych w Internecie w postaci raportów. Trudno za źródła pierwotne uznać wyniki badań opinii publicznej. Jednym z rzeczywistych źródeł analizowanych przez autorkę jest wybór pism kaznodziei Jonathana Edwardsa, ale w tym przypadku autorka również nie musiała przeprowadzić poszukiwań archiwalnych, gdyż zbiór ten ukazał się drukiem w roku 2014. Konfuzję budzi sekcja B bibliografii. Zawiera ona adresy URL stron domowych instytucji, a te nie są źródłami. W zasadzie sporządzona została według zupełnie niejasnych kryteriów. Konfuzja wzmaga się, kiedy zajrzymy do nieuporządkowanej sekcji C, zawierającej artykuły. Niektóre z przytoczonych opublikowano w drukowanej formie, inne w elektronicznej. Dlaczego autorka nie wyodrębniła tych dostępnych w internecie w osobnej części - nie wiadomo. Podobnie dzieje się zresztą w sekcji A, gdzie materiały drukowane mieszają się z internetowymi. Wydaje się, że Napierała nie potrafi pogrupować i zhierarchizować wykorzystanych materiałów i układa je w najprostszy sposób, czyli alfabetycznie.

W rozdziale 1 (,Zagadnienia wprowadzające. Terminologia”, s. 17-44) zostały określone podstawowe problemy badawcze. W jego pierwszej części autorka zastanawia się, czym jest sfera publiczna, w drugiej - czym jest religia, aby następnie zawężyć problematykę do religii obywatelskiej, Kościołów, sekt, denominacji i sekularyzacji. Wbrew zastrzeżeniu poczynionemu w pierwszym akapicie rozdział ten jest w istocie „wyczerpującym wykładem teoretycznym”. Autorka sama powinna wskazać, które definicje wspomnianych terminów przyjmuje w swojej pracy. Rozczarowująca jest ostatnia część tego rozdziału, pozbawiona wniosków i komentarzy. Po dotychczasowej lekturze wydaje się, że to, co kluczowe w amerykańskiej religii obywatelskiej - niesprecyzowany po kątem konkretnej religii Bóg, religia jako czynnik legitymizujący porządek państwowy i prawodawstwo, religijne aspekty niektórych uroczystości państwowych, koncepcja narodu wybranego, poczucie wyjątkowości, idea Nowego Izraela, ofiary i odrodzenia po wojnie secesyjnej, rywalizacja ideologiczna z komunizmem w czasie zimnej wojny - zostało zepchnięte na margines i przytłoczone niepotrzebnymi detalami. W moim odczuciu rozdział ma zakłócone proporcje, a autorka znacznie lepiej radzi sobie na polu prezentacji niż syntetycznej konkluzji wykorzystanych badań.

W rozdziale drugim („Rola religii w okresie kształtowania się społeczeństwa amerykańskiego", s. 45-87) religia została przedstawiona jako czynnik kształtujący tożsamość osadników i kolonistów. Jego wstępna część jest krótkim zarysem 
doktryny luteranizmu, kalwinizmu, purytanizmu i separatyzmu. Luteranizmowi można było poświęcić mniej uwagi, z kolei fragment o purytanizmie rozbija bardzo długa i szczegółowa prezentacja dziejów anglikanizmu. To nieodpowiednie rozłożenie akcentów spowodowało, że zabrakło miejsca na przedstawienie poglądów autorki na temat tego, jak ukształtował się porządek społeczno-polityczny pod wpływem tych religii. W kolejnych partiach rozdziału zostały zaprezentowane znane informacje o funkcjonowaniu i organizacji purytańskiej kolonii Massachusetts, lecz mniej uwagi poświęcono religijności jej mieszkańców w codziennym i niepolitycznym wymiarze. $\mathrm{O}$ wpływie religii na obyczajowość napisano zaledwie jeden akapit (s. 59-60), marginalnie omówiono jej wpływ na szkolnictwo. Trafne są za to uwagi autorki o często niedostrzeganej nietolerancji purytanów wobec innych wyznań - ale wydarzenia z Salem z 1692 roku ledwie wspomniano, i to bez podania daty. W książce Napierały nie odnajdziemy też interpretacji kazania Johna Winthropa z 1630 roku A Model of Christian Charity z frazą o „mieście na wzgórzu”, kluczowego dla zrozumienia organizacji społeczeństwa tej kolonii i roli Kościoła w niej. W kolejnych partiach książki autorka omówiła zróżnicowanie religijne innych kolonii pierwsze wielkie przebudzenie, ale znów jedynie od strony religijnej i bez wskazania, czy miało ono wymierny i zauważalny wpływ na codzienność Amerykanów i ich inne niż polityczno-ideologiczne postawy. Czyje poglądy kształtowało? Jaki był jego zasięg terytorialny i czym tłumaczy się jego popularność? Ciekawie pisze autorka o religijnym wymiarze wojny z Wielką Brytanią i uwzględnieniu Boga w Deklaracji Niepodległości, podkreślając, że stanowi ona podsumowanie poglądów Amerykanów na wszelkie sfery życia społeczno-politycznego

W rozdziale 3 („,Rozwiązania prawne dotyczące religii w nowej republice”, s. 89112) zostały opisane wydarzenia od uznaniem niepodległości kolonii przez Wielką Brytanię (1783) do roku 1795, w którym autorka doszukuje się początków drugiego wielkiego przebudzenia. Pierwsza część tego rozdziału dotyczy prawodawstwa poszczególnych stanów w odniesieniu do religii, następnie omówione zostały poglądy ojców założycieli na relacje państwa z Kościołem (a właściwie religią), w części trzeciej części opisano umocowanie konstytucyjne religii, w czwartej - interpretację pierwszej poprawki, a w zakończeniu przedstawiono kształtowanie się początków religii obywatelskiej. Rozdział uznać należy za poprawnie skonstruowany i przejrzysty, choć niepozbawiony przydługich rozważań (np. na s. 101) i hermetyczny w miejscu wykładu na temat interpretacji pierwszej poprawki. Miejscami autorka wchodzi głęboko w XIX i XX wiek (s. 109) i rozbija tym na krótko narrację tej części pracy. Zdecydowanie więcej uwagi poświęciłbym religii obywatelskiej i lepszemu przedstawieniu jej kontekstów poprzez przytoczone wcześniej interpretacje. Obecnie jej omówienie zajmuje zaledwie jeden akapit (s. 111) i jest nieproporcjonalnie krótkie w stosunku do wcześniejszych szczegółowych rozważań. Przekonująco ukazano czynniki kształtujące religijność mieszkańców nowo nabytego terytorium - stanu Luizjana. Łączyły się z szerszymi zjawiskami społecznymi pierwszej połowy XIX wieku, zwanej erą zwykłego człowieka. Kontrowersyjne trzecie wielkie przebudzenie, trwające około pięćdziesięciu lat, zostało sprowadzone do działalności Dwighta L. Moody'ego i jego chicagowskiego Instytutu Biblijnego, którego wkład 
w rozwój amerykańskiej religijności ograniczono do nadania religii formy korporacyjnej i wprowadzeniu muzyki przy jednoczesnym spłyceniu doktryny. Brakuje oceny tego zjawiska, autorka pisze jedynie ogólnie, że wywierało ono „coraz większy wpływ na kształtowanie wartości kulturowych XIX-wiecznej Ameryki” (s. 119), a jego uczestnicy często podejmowali narastający problem zniesienia niewolnictwa, co nie powinno dziwić, gdyż toczył się wtedy ostry spór w tej kwestii i powszechnie stosowano w nim argumentację religijną. Sądzę, że powinno się podejść do trzeciego wielkiego przebudzenia bardziej krytycznie i porównując je z poprzednimi, zastanowić się nad jego charakterem. Jego apologeta, William G. McLaughlin, oparł się na zbyt prostym moim zdaniem skojarzeniu nasilającego się politycznego napięcia w kwestii niewolnictwa - zwiastującego drugie przyjście Chrystusa - z religijnym fermentem na tym tle. Wydaje się, że poza podziałami politycznymi przebudzenie nie zostawiło większych śladów w mentalności społeczeństwa USA i nie wpłynęło na religię w następnych latach. Nie kojarzyłbym go także z chrześcijańskim ruchem trzeźwościowym końca XIX wieku. Oceniając wpływy obu przebudzeń, autorka powściągliwie przedstawia skutki społeczne, polityczne i religijne, do których zalicza przede wszystkim powstawanie nowych Kościołów czy prądów religijnych. Nawet z tej części pracy wywnioskować można, że konsekwencje drugiego przebudzenia mają o wiele większy zasięg, co pytanie o trzecie przebudzenie czyni tym bardziej zasadnym.

W rozdziale 5 („Religia w okresie nasilonej imigracji z Europy”, s. 150-193) Napierała próbuje odpowiedzieć na pytanie, jakie zaszły zmiany w religijności społeczeństwa Stanów Zjednoczonych pod wpływem napływu Europejczyków na kontynent amerykański na przełomie XIX i XX wieku. Wpływ ten jest wielowymiarowy i nie można go w żaden sposób zignorować, pojawia się jednak pytanie o periodyzację. Autorka podporządkowała ją dziejom politycznym i starała się dopasować do nich ewolucję religii i religijności Amerykanów. Do połowy XIX wieku wydaje się to zasadne, ponieważ taka zbieżność rzeczywiście zachodzi, trudniej to jednak usprawiedliwić po wojnie secesyjnej. Imigracja drugiej połowy XIX wieku znacznie wykracza poza datę przełomu wieków i jest przede wszystkim zjawiskiem społecznym, a nie religijnym. Rodzi się więc pytanie: czy na chronologię polityczno-religijną wolno nałożyć inną, z odrębnej dziedziny? Odmienną kwestią jest datowanie zjawiska. Narracja wskazuje, że mowa jest o drugiej połowie XIX wieku, ale nasilona imigracja Europejczyków do USA odbywała się też w jego pierwszej połowie. Znajdujemy wprawdzie daty 1848-1917, lecz ich wyboru autorka ani nie uzasadnia, ani nie komentuje i właściwie nie wiadomo dlaczego zostały wybrane.

Ta część pracy przedstawia na wstępie zarys amerykańskiego prawa emigracyjnego, aby następnie przejść do ukazania związków między imigracją a religią i lęków, jakie napływ obcych wywoływał u Amerykanów. Narracja prowadzona jest w ciekawy sposób, ale w pewnej chwili przeradza się w zarys historii rozwoju amerykańskich uprzedzeń wobec katolicyzmu, przejawiających się werbalną i fizyczną niechęcią oraz manifestowaniem patriotyzmu i amerykanizmu głównie przez Irlandczyków. Szkoda, że autorka nie spojrzała na katolicyzm ze strony czysto społecznej i religijnej i pominęła na przykład budownictwo sakralne, działalność zakonów 
i parafii, a przede wszystkim szeroko pojęte szkolnictwo każdego szczebla. Zwraca to uwagę zwłaszcza dlatego, że Napierała prowadziła swe badania w Boston College, jezuickiej uczelni założonej w 1863 roku właśnie w celu kompensowania dyskryminacji i z zamiarem stworzenia własnej elity intelektualnej wśród bostońskich katolików. Obecność religii w dalszych partiach tego rozdziału jest przysłonięta detalami ze świata polityki (s. 185 i nast.) i rozważaniami na temat kwestii religijnych w ideach i działaniach reformatorów społecznych końca XIX wieku.

Rozdział 6 („Religia w sferze publicznej w pierwszej połowie XX wieku”) jest wyjątkowo krótki, autorka omawia w nim przewartościowania w społeczeństwie USA widziane przez pryzmat religii, jednak bez kontekstu historycznego. Faktem jest, że zrodził się fundamentalizm i powstały podziały w protestantyzmie, ale dlaczego wystąpiły i zanikły (s. 202)? Nie znalazłem też odpowiedzi na pytanie z czego czerpał fundamentalizm przed rokiem 1917 i czy faktycznie zniknął po roku 1925? Jakie czynniki, procesy, które mogły doprowadzić do jego osłabienia, wystąpiły wtedy w USA? Wewnętrzne dzieje Stanów Zjednoczonych wskazują, że miał się całkiem dobrze w latach 30.i 40., a wyraźnie umocnił się w latach antykomunistycznych nastrojów lat 50. Dość pobieżnie potraktowano proces Scopesa, bez uwzględnienia jego genezy, przebiegu i znaczenia, rozumiany jako spór „starego" $\mathrm{z}$,nowym”, o wymiarze innym niż tylko religijny. Chybiony jest zarzut (w przypisie na s. 203), że „moderniści” wyznawali poglądy eugeniczne - w latach 20. prawie nikt nie traktował eugeniki jako czegoś złego. Jej krytyka i odrzucenie nastąpiły dopiero po zastosowaniu jej przez hitlerowskie Niemcy i napiętnowaniu przez proces norymberski. W końcowych partiach rozdziału znajdujemy więcej odniesień do polityki niż do religii, zabrakło na przykład omówienia inicjatyw społecznych, takich jak działalność Dorothy Day i jej organizacji Catholic Worker czy generalnie przejawów religijności przeciętnych Amerykanów. Inną kwestią jest zupełnie pominięta druga wojna światowa. Czy nie miała ona żadnego religijnego wymiaru? Czy ówczesna retoryka, patriotyzm, walka na froncie nie miały żadnego religijnego kontekstu, żadnych religijnych odniesień? Na próżno szukać także choćby wzmianki o działalności księdza Charlesa Coughlina, energicznego, ogromnie popularnego i kontrowersyjnego kaznodziei z połowy lat 30 .

W rozdziale 7 („Rola religii w amerykańskiej sferze publicznej w drugiej połowie XX wieku...”) została ukazana religijność po 1945 roku i w pierwszych latach XXI wieku. Rozdział zaczyna się od omówienia wpływu II wojny światowej na głównie amerykańskie nurty religijne i niestety rozczarowuje, jest to bowiem przypomnienie różnych wydarzeń politycznych, którym próbuje nadać się kontekst religijny. Z pracy nie wynika jasno, jaki ten wpływ był i jak wojna zmieniała na przykład postrzeganie katolików przez protestanckich Amerykanów. W tej części miesza się także chronologia, jako że autorka wychodzi daleko poza bezpośrednie skutki wojny i wspomina na przykład senatora Josepha McCarthy'ego czy pacyfistyczny ruch SANE. Wymiar polityczno-religijny czasów powojennych był znacznie bardziej złożony. Pisze o tym Jonathan P. Herzog w pracy The Spiritual-Industrial Complex (Oxford 2011), ukazując wiarę i Boga jako nacechowany silnymi emocjami zwornik patriotycznych i antykomunistycznych postaw Amerykanów wczesnej zimnej 
wojny. Autorka wspomina o tym marginalnie (s. 215-216) i nie wiąże działalności przedstawionego dalej fundamentalistycznego kaznodziei Billy'ego Grahama z tymi postawami. Drobnej wzmianki doczekał się ogromnie wpływowy kardynał Francis Spellman, pominięci zostali arcybiskup Fulton J. Sheen czy publicysta William F. Buckley.

Przemianom lat 60 . i 70. w kontekście religijności poświęcony został krótki (s. 223-229) przegląd wydarzeń w Kościołach skupiających osoby czarnoskóre, zapewne dlatego, że ruch praw obywatelskich i jego radykalna emanacja w drugiej połowie XX wieku odcisnęła w historii mocne piętno. Napierała komentuje poglądy Narodu Islamu przed przedstawieniem jego genezy i założeń (s. 226-227), pomija wydarzenia w Kościołach skupiających przede wszystkich osoby białoskóre, Sobór Watykański II i jego konsekwencje, generacyjny kryzys wśród katolików i protestantów głównego nurtu, pojawienie się nurtów i sekt inspirowanych religiami Wschodu, powstanie nowych ruchów religijnych i komun jako form życia wspólnotowego i poszukiwania nietradycyjnej duchowości. Przez pryzmat polityczny ukazano także lata 80. Brak odniesień do szerszych zjawisk społecznych sprawił, że religijność została sprowadzona jedynie do marginalnie wspomnianych Latynosów i ich znaczenia dla katolicyzmu. Tak samo potraktowano prawicę religijną końca lat 70 . XX wieku. Zaburzenie proporcji widać szczególnie dobrze, gdy porówna się objętość podrozdziału 7.4 (s. 239-258) i 7.5 (s. 258-265), traktującego o współczesnych zjawiskach w religijności Amerykanów. Ledwie dostrzeżono zjawisko megakościołów (s. 264), tymczasem jest to fenomen liczący się politycznie, społecznie i religijnie, a działający w nich kaznodzieje są niezwykle wpływowymi postaciami. Nie nadmieniono o silnym kontekście religijno-politycznym oblężenia farmy w Waco w 1993 roku, gdzie w akcji FBI zginęło 74 wyznawców sekty Davida Koresha. Wydarzenie to stawia wiele pytań o skrajne formy religijności mieszkańców USA.

Kończący książkę rozdział 8 („Obecność religii w sferze publicznej USA w kontekście teorii naukowych", s. 267-292) stanowi zestawienie i streszczenie (por. przypisy na s. 272-275) poglądów badaczy funkcjonowania religii w przestrzeni publicznej. Ten bardzo teoretyczny materiał widziałbym jako podrozdział we wstępnych częściach pracy z racji jego przeglądowego charakteru. W zakończeniu, gdzie powinny znaleźć się wnioski wynikające z całej pracy, mamy zaledwie jednostronicowy komentarz o poprawności postawionej hipotezy i potwierdzeniu jej w trakcie badań.

Autorka opisuje zjawisko religijności Amerykanów z perspektywy politologa i w jej pracy brakuje mi historii społecznej i religii - na przykład sakralizacji przestrzeni przez kościoły, uniwersytety, inne placówki o religijnym charakterze. Napierała pomija zaangażowanie laikatu $\mathrm{w}$ takie kwestie jak symbole religijne $\mathrm{w}$ instytucjach publicznych, aborcja czy eutanazja. Często dokładnie streszcza poglądy innych autorów - można było dokonać ich syntezy, a czytelnika odesłać bezpośrednio do literatury przedmiotu przy pomocy przypisów. Zbyt długie są opisy sytuacji w koloniach, powszechnie przecież znane. W pracy zdecydowanie przeważa prezentacja wydarzeń z początków historii USA i z XIX wieku, następne stulecie opisano skrótowo i ogólnie, a zjawiska z dwóch pierwszych dekad XXI wieku są zaledwie wspomniane. Przy opisie teorii boskiego przeznaczenia warto było dodać opinię Hermana 
Melville'a o tym, że Amerykanie są „przedziwnym, wybranym narodem - Izraelem naszych czasów", co niesie wyraźnie religijne skojarzenia.

Autorka tworzy długie i szczegółowe akapity, utrudniające przyswojenie zawartych w nim informacji. Zdarzają się anglicyzmy (najbardziej drastyczny przykład to przypis na stronie 123: „Kościół katolicki rozpoznawał na przykład ich prawo do zawierania małżeństw” - chodzi zapewne o słowo „recognised” znaczące w tym kontekście „uznawał”) oraz amerykańska interpunkcja. Na stronie 169 wkradł się przykry błąd ortograficzny.

Z książki In God We Trust. Religia w sferze publicznej USA mniej będą zadowoleni czytelnicy zainteresowani amerykańską religijnością i historią religii tego kraju. Praca Napierały zasługuje jednak na uwagę politologów i osób szukających odpowiedzi na pytanie o powstanie i kształtowanie się amerykańskiej religii obywatelskiej oraz rozumienia miejsca Boga w przestrzeni publicznej. 